\title{
Vyhlášení cen Premio Boulvert a konference Diritto romano e attualità
}

\author{
16.-22. listopadu 2019, Praha
}

Dne 20. listopadu 2019 se v Malé aule Karolina předávaly ceny Premio Boulvert a zároveň byla zahájena tradiční každoroční konference Diritto romano e attualità. Obě dvě akce se konaly pod organizační záštitou Katedry právních dějin Právnické fakulty Univerzity Karlovy.

\section{Představení obou akcí}

Premio Boulvert je prestižní ocenění udělované od roku 1987 mladým vědcům z celého světa za nejlepší první autorskou monografii z oblasti římského práva a práv starověku. Toto ocenění má přispívat k rozvoji právní romanistiky a posouvat vpřed vědeckou činnost začínajících vědců. Premio Boulvert vznikla z iniciativy redakční rady časopisu Index, vydávaného v Neapoli, a je udělována Meziuniverzitní společností Gérard Boulvert (Consorzio Interuniversitario Gérard Boulvert) založenou několika italskými univerzitami. Nositeli této ceny je celá řada celosvětově uznávaných vědců, kteří v současné době působí jako ordináři právní romanistiky. $\mathrm{O}$ vítězi rozhoduje odborná porota složená z předních evropských i mimoevropských romanistů. Vybírá se z přihlášených monografií vydaných ve třech letech předcházejících roku, v němž se cena uděluje. Udílení ceny Premio Boulvert hostily v minulosti univerzity v Neapoli, Bonnu, Catanii, Římě, Salzburgu a Paříži. Zasedání komise a vyhlášení ceny Premio Boulvert je pro pořádající instituci velmi prestižní záležitostí, jednou z nejdůležitějších romanistických akcí, jíž se účastní nejvýznamnější romanisté z celého světa. Cena Premio Boulvert obdržela medaili prezidenta Italské republiky.

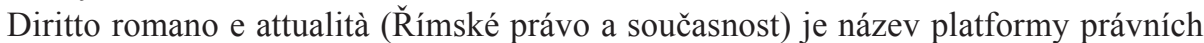
romanistů, která pořádá každoročně konference zaměřující se na různé oblasti římského práva. Založili ji představitelé právní romanistiky ze tří univerzit - Michal Skřejpek (Univerzita Karlova, Právnická fakulta), Konstantin Tanev (Interuniversity Centre for Studies of Roman law and Romanistic Tradition with UNWE) a Leonid Kofanov (Institute of World History, Russian Academy of Sciences, Centre of Roman Law Studies a Russian State University of Justice). Tito tři profesoři, společně s profesorem Osvaldem Sacchim (Università degli Studi di Campania Luigi Vanvitelli, Dipartimento di Giurisprudenza) tvoří stálý vědecký výbor. Postupně se k této platformě přidali další evropští i světoví romanisté. V pořádání konferencí Diritto romano e attualità se stř́idají jednotlivé univerzity, přičemž v roce 2019 se konal v Praze již XV. ročník mezinárodní romanistické konference, a to na téma Consolidamento e sviluppi degli assetti costituzionali nella libera res publica (Ustálení a vývoj ústavních aspektů římské republiky). 


\section{Jednání komise Premio Boulvert}

V rámci 11. ročníku vyhlašování ceny Premio Boulvert komise posuzovala celkem 32 publikací vydaných v letech 2016, 2017 a 2018, přihlášených do soutěže do 31. prosince 2018 (seznam autorů a jejich děl je přiložen $\mathrm{v}$ závěru této zprávy). Hodnocení vždy probíhá ve dvou fázích, při nichž se komise osobně sejde a analyzuje jednotlivé publikace na základě písemných posudků, které na každou z nich zpracovává více členů komise. První, předběžná fáze hodnocení proběhla v červnu 2019 ve Friburgu (Švýcarsko), druhá, rozhodující fáze pak v Praze. Záštitu nad vyhlášením ceny Premio Boulvert převzal předseda Nejvyššího soudu ČR, prof. JUDr. Pavel Šámal, Ph.D., rektor Univerzity Karlovy, prof. MUDr. Tomáš Zima, DrSc. MBA, a děkan Právnické fakulty UK, prof. JUDr. Jan Kuklík, DrSc.

Komise se sešla v hotelu Belvedere a jednala za zavřenými dveřmi o udělení ceny ve dnech 16.-19. listopadu 2019. Členové komise, kteří se jednání zúčastnili osobně byli Alessandro Corbino, prezident komise (Katánie, Itálie), Cosimo Cascione (Neapol, Itálie), Maria Floriana Cursi (Řím, Itálie), Teresa Giménez-Candela (Barcelona, Španělsko), Fausto Goria (Turín, Itálie), Éva Jakab (Szeged, Mad’arsko), Luigi Labruna, čestný prezident a emeritní člen (Neapol, Itálie), Carla Masi Doria (Neapol, Itálie), Thomas A. J. McGinn (Nashville, USA), Pascal Pichonnaz (Fribourg, Švýcarsko), Johannes Michael Rainer (Salzburg, Rakousko), Martin Schermaier (Bonn, Německo) a Laurens Winkel (Rotterdam, Nizozemsko). Komise dále sestává z emeritních členů, mezi něž patř́ Jean Andreau (Paříž, Francie), Luigi Capogrossi Colognesi (Ř́m, Itálie), Michel Humbert (Paříž, Francie), a Gunter Wesener (Graz, Rakousko), kteří však závěrečnému jednání komise nebyli př́tomni.

Komise rozhodovala tradičně nejen o laureátovi hlavní ceny Premio Boulvert, ale také o udělení speciálních cen romanistických center a institutů zahraničních univerzit dalším z přihlášených autorů, jejichž díla jsou hodná zvláštní pozornosti pro svou vědeckou kvalitu.

Poté, co se dne 19. listopadu 2019 komise jednomyslně usnesla na tom, komu udělí př́islušné ceny speciální i cenu hlavní, sešli se členové komise s autory hodnocených monografí, kteří přijeli na vyhlášení do Prahy, a s organizátory akce z PF UK ke slavnostní gala večeři. Tak se konala na salónní rychlolodi Nepomuk, kde byli všichni účastníci nejprve přivítáni hlavním organizátorem akce, Michalem Skřejpkem, a prezidentem komise, Alessandrem Corbinem. $V$ průběhu tř́hodinové plavby spojené s večeří, kde atmosféru dotvářel hudební doprovod a účastníci měli možnost shlédnout krásy Prahy z netradičního pohledu z Vltavy, se předávaly prŕtomným autorům také pamětní medaile na účast $\mathrm{v}$ soutěži o cenu Premio Boulvert.

\section{Vyhlášení ceny Premio Boulvert a zahájení konference Diritto romano e attualità}

Slavnostní vyhlášení ceny Premio Boulvert se konalo dne 20. listopadu 2019 v Malé Aule Karolina, kde byla zároveň zahájena navazující akce, konference Diritto romano e attualità.

Akce byla zahájena v 10 hod. úvodními proslovy proděkana PF UK, Michala Tomáška, a prezidenta komise Premio Boulvert, Alessandra Corbina. Za předsednictví Luigiho Labruny byly předneseny první dva římskoprávní konferenční př́íspěvky. Cosimo Cascione (Università degli Studi di Napoli Federico II) hovořil na téma I fondamenti culturali del Governo repubblicano (Kulturní základy republikánské vlády) a Johannes Michael Rainer (Universität Salzburg) přednesl př́spěvek Montesquieu e i Romani (Montesquieu a Římané). Předtím, než slavnostní shromáždění vyvrcholilo vyhlášením speciálních 
i hlavní ceny Premio Boulvert, si přítomní vyslechli ještě zdravici prorektorky UK, Radky Wildové.

Rozhodnutí komise přednesla přítomným tajemnice Consorzia Boulvert, Valeria di Nisio. Komise nejprve konstatovala potěšení nad vysokou kvalitou předložených prací, které napomáhají k rozvoji romanistické vědy. Byly vyzdviženy práce Annarosy Gallo (Bari, Itálie), Kimberley Czajkowski (Edinburgh, Velká Británie) a François Lerouxela (Paříž, Francie), které sice neobdržely konkrétní ocenění, ale komise je vyhodnotila jako významné, at' už z hlediska shromážděných zdrojů a jejich analýzy či zajímavých postřehů a závěrů $\mathrm{k}$ př́íslušnému tématu.

Speciální cenu „Centro interdipertimentale ,Vincenzo Arangio-Ruiz“ di studi storici e giuridici sul mondo antico“ získala Donatella Monteverdi (Catanzaro, Itálie) se svým dílem La questione decemvirale. Itinerari e risultati di una complessa vicenda storiografica, jíž cenu předala Carla Masi Doria.

Další speciální cenu „Rolf Knütel“" od Fondazione Stichting Rechtshistorisch Fonds Mr Joseph Winkel obdržela monografie Potestas alienandi. Transfer of ownership by a non-owner from Roman law to the DCFR, jejímž autorem je Javier E. Rodríguez Díez (Santiago de Chile, Chile), který se však z důvodu plnění akademických povinností nemohl předávání zúčastnit.

Následovalo vyhlášení speciální ceny „Hans Ankum“ od Fondazione Stichting Rechtshistorisch Fonds Mr Joseph Winkel, kterou z rukou Laurense Winkela převzal Salvatore Marino (Barcelona, Španělsko) za svou první autorskou monografii Sull'accessorietà del pegno per la giurisprudenza romana.

Speciální cenu „Henryk Kupiszewski“ od Centro romanistico internazionale Copanello předal Michal Skřejpek Lise Isole (Vídeň, Rakousko) za knihu Venire contra factum proprium. Herkunft und Grundlagen eines sprichwörtlichen Rechtsprinzips.

Dalším laureátem speciální ceny Institut de Droit romain de l’Université Paris II se stal Alessandro Cusmà Piccione (Messina, Itálie) za dílo ,Non licet tibi alienigenam accipere . Studio sulla disparitas cultus tra i congiugi nella riflessione cristiana e nella legislazione tardoantica. Předání ceny se zhostil Cosimo Cascione.

Z rukou Pascala Pichonnaze následně speciální cenu Faculté de droit de l'Université de Fribourg dostal Paolo Marra (Milano, Itálie), jenž je autorem knihy Fiduciae causa.

Poslední speciální cenu Corte Costituzionale della Repubblica italiana (Ústavního soudu Italské republiky) obdržela Elsemieke Stephanie Daalder (Leiden, Nizozemsko) za monografii s názvem De rechtspraakverzamelingen van Julius Paulus. Recht en rechtvaardigheid in de rechterlijke uitspraken van keizer Septimius Severus. Cena jí z důvodu nepř́itomnosti následně byla zaslána.

Výše uvedené práce byly vybrány především pro jejich zásadní dopad pro romanistiku, spočívající v detailní analýze a exegezi zdrojů, která umožňuje hlubší poznání a porozumění zkoumaným problémům, inovativních myšlenkách a závěrech vystavěných na solidní argumentaci.

Vrcholem však bylo udělení hlavní ceny XI Premio Romanistico Internazionale ,Gérard Boulvert‘. Tu, společně s medailí Univerzity „Federico II“"v Neapoli, získal Gregor Albers (Bonn, Německo), autor monografie Perpetuatio obligationis. Leistungspflicht trotz Unmöglichkeit im klassischen Recht. Komise se usnesla na následujícím hodnocení výše uvedené monografie: „Dílo nejvyšší kvality, dobře strukturované a přesvědčivé, v němž je 
k dotčenému problému přistupováno za současného pečlivého uvážení souvisejících textů a doktrinálních myšlenek, za použití velmi vyspělé vědecké metodiky, která přináši jasné a přesné dogmatické závěry, které mají svůj základ v historii.“

Tato část akce byla zakončena slavnostním rautem v recepčních prostorách Karolina. Poté se účastníci přesunuli do společenského sálu hotelu Belvedere, kde odpoledne a následně ve dnech 21.-22. listopadu 2019 pokračovala konference Diritto romano e attualità.

\section{Konference Diritto romano e attualità}

Jak již bylo uvedeno, tématem konference bylo zkoumání veřejnoprávních otázek v období konsolidace a zakotvení republikánského státního zřízení v Římě. Jednání tak navázalo na předchozí ročník konaný v roce 2018 v Catanzaru, Itálie, kdy účastníci konference zkoumali časové rozpětí od poloviny 8 . stol. př. n. 1. po polovinu 5. stol. př. n. $1 .{ }^{1}$ Cílem konferencí v letech 2018-2020 je komplexní zmapování veřejnoprávních aspektů římské republiky od jejích počátků až po její úpadek a postupnou transformaci v principát. Jednotliví přednášející se tak zaměřují jak na obecnější otázky týkající se právního myšlení dotčené doby, vlivů jiných státních útvarů na římskou politickou situaci, právní rád a kulturu, ale také na konkrétnější otázky a detailnější rozbor římského občanství, role a pravomocí magistratur, fungování lidových shromáždění a senátu, vztahu politiky, práva a obchodu, dopadu jednotlivých zákonů na římskou společnost, vojenských aspektů římského státu, a v neposlední řadě také na do veřejného práva spadající oblast trestní jurisdikce.

První odpolední části dne 20. listopadu 2019 předsedala Carla Masi Doria a zazněly v ní př́spěvky Laurense Winkela (Erasmus University Rotterdam) Il pensiero politico greco (Řecké politické myšlení) a Witolda Wolodkiewicze (SWPS Uniwersytet Humanistycznospołeczny, Varšava) L'ordine politico romano (Římské politické uspořádání).

Po coffee breaku následovala přednáška Marie Floriany Cursi (Roma Tor Vergata) Lo spazio della cittadinanza: dallo ius migrandi all'organizzazione municipale ( $V-I V$ secolo a.C.) (Rozměr občanství: od ius migrandi po městskou organizaci (V.-IV. století př. n. 1.)) za předsednictví Jana Zabłocki.

Dne 21. listopadu 2019 pokračovala konference dvěma dopoledními bloky. Carla Masi Doria (Università degli Studi di Napoli Federico II) hovořila na téma Formazione e caratteri del sistema magistratuale post-decemvirale (Utváření a charakter systému postdecemvirálních magistratur). Na ni navázala Eva Jakab (Szegedi Tudományegyetem) $\mathrm{s}$ prŕspěvkem Responsabilità dei magistrati. Visione ateniese e visione romana (Odpovědnost magistrátů. Aténský a rrímský pohled). Následnou diskusi řídil předsedající, Leonid Kofanov.

V druhém bloku se představilo pět přednášejících za předsednictví Laurense Winkela: Jan Zabłocki (Cardinal Stefan Wyszyński University w Warszawie), jehož téma znělo Contione e comitia alla luce delle Noctes Atticae di Aulo Gellio (Contione a comitia ve světle Noctes Atticae Aula Gellia), následovala Anna Tarwacka (Cardinal Stefan Wyszyński University w Warszawie) a Il carattere particolare della collegialità censoria (Zvláštní charakter censorské kolegiality). Po ní vystoupil Natale Rampazzo (Università degli Studi

Viz zpráva FALADA, D. XIV. mezinárodní seminář „Diritto romano e attualità“. Právněhistorické studie, 2019 , roč. 49 , č. 2 , s. 250-251. 
di Napoli Federico II) na téma Procedure elettorali e 'rappresentatività' dei magistrati (Volební postup a „reprezentativnost“ magistrátů). Paola Santini (Università degli Studi di Napoli Federico II) si zvolila analýzu otázky Immagini del potere e funzionamento della coercizione (Výrazy moci a fungování coercizione (kázeňské pravomoci magistrátů)). Na závěr vystoupil Stoyan Lazarov (University of National and World Economy, Sofie) a krátce shrnul téma L'abuso di potere da parte dei magistrati (Zneužití moci ze strany magistrátů).

Po obědě byl pro účastníky konference naplánován kulturní program. Nejprve se projeli historickou tramvají s průvodcem centrem Prahy a měli tak možnost vidět nejvýznamnější památky a místa (např. Pražský hrad, Rudolfinum, Národní divadlo, Národní muzeum, náměstí Republiky atd.). Po krátké procházce přes Hradčany následovala prohlídka nádherné Strahovské knihovny opět s odborným výkladem. Večeře ve Velké klášterní restauraci bylo ozvláštněna vystoupením skupiny Ambrosia, která předvedla několik historických scénických tanců a také ohňovou show.

Třetí a poslední konferenční den (22. listopadu 2019) přinesl další velmi zajímavé příspěvky, spojené pod jednotným tématem konference. Alessandro Corbino předsedal první dopolední části, v níž hovořil Leonid Kofanov (Russian State University of Justice, Moskva) na téma Composizione, lectio e competenze del senatus alto-repubblicano (Složení, doplnění a kompetence senátu rané republiky) a Thomas A. J. McGinn (Vanderbilt University, Nashville) L'identità romana alla prova del multiculturalismo. Fides romana e nuovi costumi (i Romani nel tempo di Plauto) (Římská identita jako důkaz multikulturalismu. Římská víra a nové mravy (Římané v čase Plauta)).

Po krátké pauze na občerstvení za řečnický pult usedl David Falada (Univerzita Karlova, Praha), Konstantin Tanev (University of National and World Economy, Sofie) a Osvaldo Sacchi (Università degli Studi di Campania Luigi Vanvitelli, Santa Maria Capua Vetere). Prvně jmenovaný se věnoval tématu Attività dei magistrati repubblicani domi et militiae (Činnost republikánských magistrátů domi et militiae), druhý přednášející pak přednesl prŕpěvek Aspetti legislativi del regime personale e territoriale dei debitori (Legislativní aspekty osobního a územního režimu dlužníků). Poslední řečník se zabýval tématem $L a$ nozione di ager privatus nella libera res publica e nella costruzione giuridico-istituzionale del circolo scipionico (Pojem ager privatus v římské republice a právně-institucionální konstrukci Scipionova kruhu). Této sekci předsedal Roberto Fiori, který ŕídil následnou bohatou diskusi.

Po obědě se konalo jednání platformy Diritto romano e attualità, při němž se diskutoval příští ročník konference, místo a datum jejího konání, a další organizační záležitosti.

V první odpolední části, řízené Cosimem Cascione, zazněly př́íspěvky z úst Jana Šejdla (Univerzita Karlova, Praha) Hasta - nota minima sul simbolo (Hasta - několik poznámek k symbolu), Lyuby Radulové (Sofia University „St. Kliment Ohridski“) Panem et circenses - le leges sumptuariae e le leges de ambitu nel quadro delle campagne elettorali (Panem et circenses - leges sumptuariae a leges de ambitu v souvislosti s volební kampaní), Piotra Niczyporuka (Uniwersytet w Białymstoku) Mensarii come banchieri pubblici (Mensarii jako veřejní bankéři), a Giovanny D. Meroly (Università degli Studi di Napoli Federico II) Affari e politica. Rapporto tra trasformazioni economiche e istituzionali (Obchod a politika. Vztah mezi hospodářskými a institucionálními změnami). 
V poslední sekci, jíž předsedal Konstantin Tanev, přednášel Roberto Fiori (Roma Tor Vergata) př́spěvek La nozione di centuria dalle origini alla media repubblica (Pojem centurie v první polovině trvání republiky), a konferenci uzavřel Michal Skřejpek (Univerzita Karlova, Praha) s tématem Il tramonto degli iudicia populi. I nuovi assetti della giurisdizione criminale (Úsvit iudicia populi. Nové aspekty trestní jurisdikce).

Závěr konference patřil zhodnocení úspěšného a podnětného konferenčního jednání a bohaté diskuse následující po každém bloku příspěvků, poděkování organizátorům akce, a ze strany organizátorů také sponzorům Hlavnímu městu Praze a Pražským vodovodům a kanalizacím, a. s., bez jejichž přispění by nebylo možné akci uspořádat, a Univerzitě Karlově a Právnické fakultě UK za zázemí a podporu, kterou akci poskytly.

Některé z konferenčních příspěvků budou publikovány na stránkách následujících čísel časopisu Právněhistorické studie.

Kamila Stloukalová

doi: 10.14712/2464689X.2020.11

GREGOR ALBERS, Perpetuatio obligationis. Leistungspflicht trotz Unmöglichkeit im klassischen

Recht (Köln, Böhlau, 2018) p. xvi, 501.

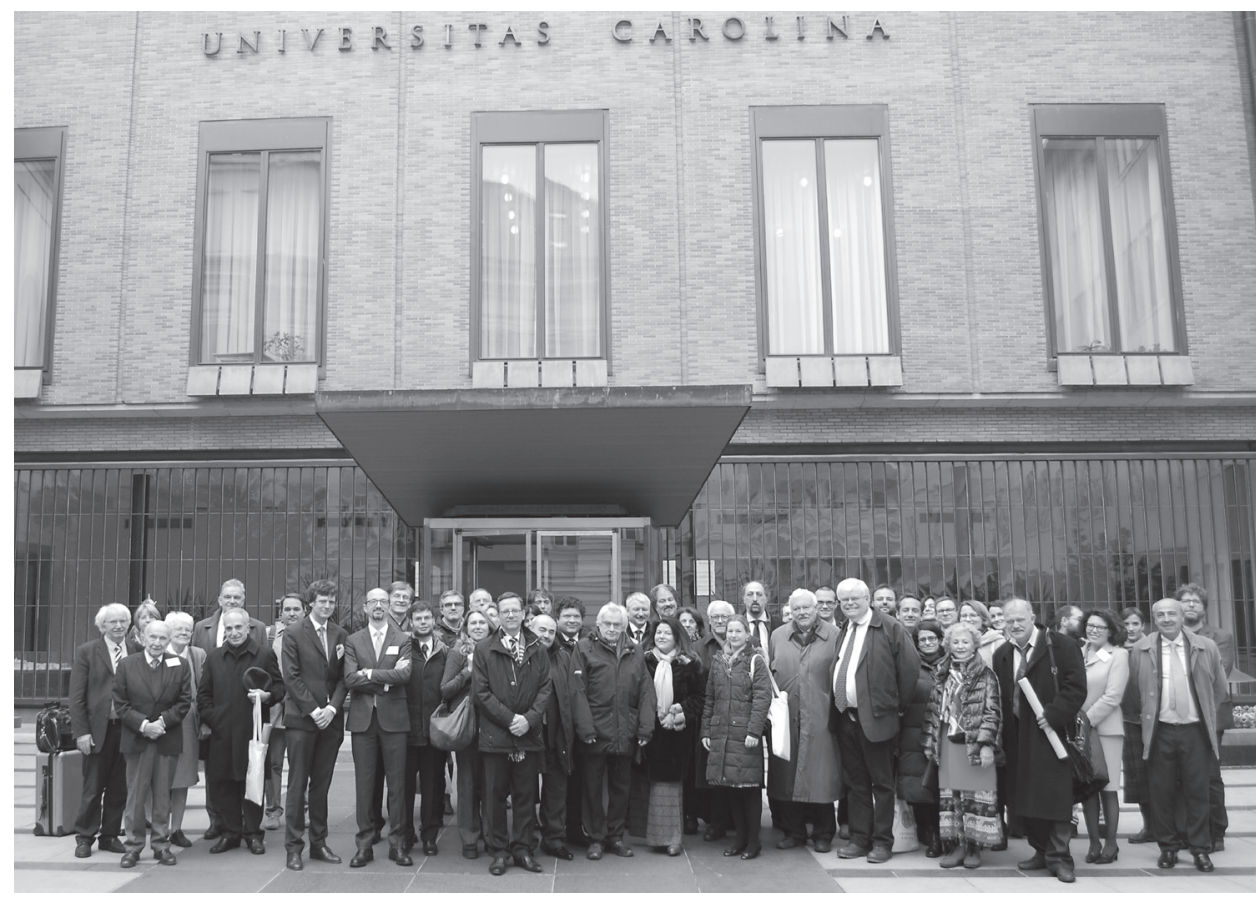

Účastníci vyhlášení ceny Premio Boulvert a zahájení konference Diritto romano e attualità před Karolinem, 20. listopadu 2019, foto: Kamila Stloukalová 


\section{Seznam autorů a děl v soutěži o cenu Premio Boulvert}

MARIATERESA AMABILE, 'Nefaria secta'. Sulla normativa imperiale 'de Iudaeis' (IV-VI secolo) (Napoli, Jovene, 2018) p. viii, 168.

DARIO ANNUNZIATA, Opulentia ecclesiae. Alle origini della proprietà ecclesiastica (Napoli, Editoriale scientifica, 2018) p. viii, 192.

GRZEGORZ JAN BLICHARZ, Udział państwa w spadku. Rzymska myśl prawna w perspektywie prawnoporównawczej (Kraków, Wydawnictwo Od.Nowa, 2016) p. 680.

NÚRIA COCH ROURA, La forma estipulatoria. Una aproximación al estudio del lenguaje directo en el Digesto (Madrid, Dykinson, 2017) p. 417.

GAETANO COLANTUONO, Unioni tardoantiche. Documenti conciliari e giuridici per una storia sociale del matrimonio nella tarda antichità (Roma, Aracne, 2018) p. 212.

ANDREA COLORIO, Enechyron. Economia, società e garanzia mobiliare del credito nell'Atene classica (Alessandria, Edizioni dell'Orso, 2018) p. viii, 128.

ALESSANDRO CUSMÀ PICCIONE, 'Non licet tibi alienigenam accipere'. Studio sulla disparitas cultus tra i coniugi nella riflessione cristiana e nella legislazione tardoantica (Milano, Giuffrè, 2017) p. xvi, 535.

KIMBERLEY CZAJKOWSKI, Localized Law: The Babatha and Salome Komaise Archives (Oxford, Oxford University Press, 2017) p. xii, 240.

ELSEMIEKE STEPHANIE DAALDER, De rechtspraakverzamelingen van Julius Paulus. Recht en rechtvaardigheid in de rechterlijke uitspraken van keizer Septimius Severus (Den Haag, Boom Juridisch, 2018) p. xii, 676.

DOMENICO DURSI, Res communes omnium. Dalle necessità economiche alla disciplina giuridica (Napoli, Jovene, 2017) p. xvi, 153.

VANESSA EINHEUSER, Studien zur lex rivi Hiberiensis. Zur Rechtsdurchsetzung innerhalb einer Bewässerungsgemeinschaft im 2. Jh. n. Chr. (Wiesbaden, Harrassowitz, 2017) p. xii, 151.

MARINA EVANGELISTI, Principato Auctoritas Solutio legibus (Torino, Giappichelli, 2018) p. xii, 250.

DORIS FORSTER, Ona'ah und laesio enormis. Preisgrenzen im talmudischen und römischen Kaufrecht (München, C. H. Beck, 2018) p. xiv, 267.

STEFANIA FUSCO, Oriens de nocte silentio: alcune riflessioni sulla dittatura imminuto iure (Ortacesus, Sandhi, 2018) p. 173.

ANNAROSA GALLO, Prefetti del pretore e prefetture. L'organizzazione dell'agro romano in Italia (IV-I sec. a.C.) (Bari, Edipuglia, 2018) p. 318.

GIOVANBATTISTA GRECO, Turpitudo. Alle origini di una categoria giuridica (Napoli, Satura, 2018) p. $x, 270$.

ALESSIO GUASCO, Gli atti introduttivi del processo civile nelle cognitiones extra ordinem (Torino, Giappichelli, 2017) p. 279.

LISA ISOLA, Venire contra factum proprium. Herkunft und Grundlagen eines sprichwörtlichen Rechtsprinzips (Frankfurt am Main, Peter Lang, 2017) p. xvi, 515.

FRANÇOIS LEROUXEL, Le marché du crédit dans le monde romain (Égypte et Campanie) (Rome, École française de Rome, 2016) p. 397.

DAVID MAGALHÃES, A evolução da protecção do arrendatário. O direito à permanência nas dependências locadas, desde o direito romano clássico (Madrid, Dykinson, 2018) p. 714.

SALVATORE MARINO, Sull'accessorietà del pegno per la giurisprudenza romana (Napoli, Jovene, 2018) p. xiv, 248.

PAOLO MARRA, Fiduciae causa (Milano, Wolters Kluwer Cedam, 2018) p. xiv, 344.

DONATELLA MONTEVERDI, La questione decemvirale. Itinerari e risultati di una complessa vicenda storiografica (Milano, Wolters Kluwer Cedam, 2018) p. xxviii, 526. 
MURIEL MOSER, Emperor and Senators in the Reign of Constantius II. Maintaining Imperial Rule between Rome and Constantinople in the Fourth Century AD (Cambridge, Cambridge University Press, 2018) p. xviii, 420.

CARMEN MACARENA PALOMO PINEL, Nec inmerito paterfamilias dicitur. El paterfamilias en el pensamiento de Lactancio (Madrid, Dykinson, 2017) p. 465.

JAVIER E. RODRÍGUEZ DIEZ, Potestas alienandi. Transfer of ownership by a non-owner from Roman law to the DCFR (Oisterwijk, Wolf Legal Publishers, 2016) p. 491.

IOLANDA RUGGIERO, Ricerche sulle Pauli Sententiae (Milano, Giuffrè, 2017) p. xiv, 487.

SEBASTIAN STEPAN, Scaevola noster. Schulgut in den 'libri disputationum' des Claudius Tryphoninus? (Tübingen, Mohr Siebeck, 2018) p. xvi, 273.

MARIOS TANTALOS, Il possesso e la sua tutela dal diritto tardo-romano a quello bizantino /

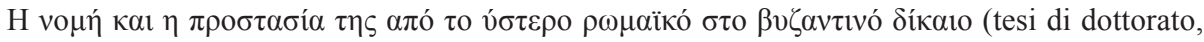
2016) p. 191.

ADOLFO WEGMANN STOCKEBRAND, Obligatio re contracta. Ein Beitrag zur sogenannten Kategorie der Realverträge im römischen Recht (Tübingen, Mohr Siebeck, 2017) p. xiv, 329.

CONSTANTIN WILLEMS, Justinian als Ökonom. Entscheidungsgründe und Entscheidungsmuster in den quinquaginta decisiones (Wien - Köln - Weimar, Böhlau, 2017) p. 537. 